\title{
Permeability of Cane Juice in Ultrafiltration Membranes of Acrylic Vinyl Co-Polymer and Cellulose Acetate ${ }^{\dagger}$
}

\author{
Masakuni Tako, Kuniya Nakamoto, Senehiga Nakamura, \\ Yoshihiro KOHDA", and Danji NomurA*" \\ "Department of Agriculbural Chemistry and Agricultural Engineering, College of \\ Agriculture, University of the Ryztkyus, Nishihara, Okinowa 909-01 \\ "Department of Food Engineering, College of Engineering, Toa \\ University, Shimonozeki, Yamaguchi $75 I$
}

\begin{abstract}
The effects of membrane permeability on the flux and quality of raw and limed cane juica on ultrafiltration were studied by $2 \sim 3 \mathrm{~h}$ long-term testing (of several types with molecular weight cut-off leveis from 50000 to 100000 ). The flux through XM-50, XM-100 and A-50 T membranes for raw juice remained at the value of about $0.100 \mathrm{ml} \cdot \mathrm{cm}^{-2} \cdot \mathrm{min}^{-1}$ until permeation volume of $250 \mathrm{ml}$, but $\mathrm{jt}$ then decreased gradually. The flux of A-50 T membrane was the greatest at the initial stage (with $0.140 \mathrm{ml} \cdot \mathrm{cm}^{-1} \cdot \mathrm{min}^{-1}$ ), and then decreased gradually when juice limed to $\mathrm{pH} 8.1$ at $10^{\circ} \mathrm{C}$ was used. The flux of juice limed to $\mathrm{pH} 7.0$ at $85^{\circ} \mathrm{C}$ showed remarksbly high value (at the initial stage), however it decreased rapidly with ineraging permeale volume. The fux of A-50 T membrane showed comparatively lower value than that of XM-membranes. The suerose rejection of the permeate with the XM-50, $\mathrm{XM}-100$ and $\mathrm{A}-50 \mathrm{~T}$ membranes was $2,2 \sim 5$ and $5 \sim 7 \%$ for juice limed to $\mathrm{pH} 7.0$ at $85^{\circ} \mathrm{C}$, respectively.
\end{abstract}

A number of studies have been done on the application of low energy techniques in sugar processing, because cane manufacturing is one of the most energy-intensive processes in the food industry". One of such technique is the ultrafiltration of raw and limed juice ${ }^{2 j-5)}$. As reported in the preceding papers ${ }^{6)-8}$, addition of lime to cane juice proped effective for incraasing the flux. When ultrafiltration was carried out with a PM-10 membrane at $80^{\circ} \mathrm{C}$ after liming at 10,30 and $85^{\circ} \mathrm{C}$, the greatest flux and highest permeate quality based on purity, and the optimum contents of $\mathrm{CaO}$ and $\mathrm{P}_{2} \mathrm{O}_{5}$ were obtained at $\mathrm{pH} 8.1,7.8$ and 7.0 , respectively ${ }^{6)}$. Such optimum conditions were also found for PM-30, YM-5 and YM-2 membranes". Furthermore, we reported previously on the menbrane permesbilities of raw and limed cane juice through two types of mem- branes (PM and YM) with molecular weight cut-off levels from 5000 to 30000 by the long-term terting, and concluded that the YM30 membrane with a nominal molecular weight exclusion limit of 30000 was suitable for ultrafiltration of raw juice, while the YM-5 membrane (5000) was more suitable for that of limed juice (limed to $\mathrm{pH} 7.0$ at $85^{\circ} \mathrm{C}$ ) ${ }^{8}$. This indicated that the membrane permeabilities of cane juice was not proportional to the molecular weight cut-off levels in a type of cellulose derivative membrane. On the other hand, the membrane of acrylic vingl copolymer are aleo developed by many membrane manufacturing companies as woll as those of cellulose derivatives".

We report here the effects of membrane permeability, with type of XM-membrane and cellulose acetate membrane with molecnlar

$\uparrow$ Presented at the 192nd Meoting of the Branch of Nishinippon, the Agric. Chem. Soc. Japan, in October 1886. 
weight cut-off levels from 50000 to 100000 , on the flux and quality of raw and limed juice on ultrafiltration, as studied by long-term testing for $2 \sim 3 \mathrm{~h}$, and discuss the applicability of the membrane process in the cane sugar industry.

\section{Materials and Methods}

\section{Cante Juice}

Suger cane (variety $\mathrm{N}$ : Co 310) grown in the fields of the University of the Ryukyus was pressed twice with a test mill to obtain the juice, which was filtered through cotton wool.

\section{Liming the cane juice}

The cane juice $(400 \mathrm{ml})$ was limed to $\mathrm{pH}$ 8.1 at $10^{\circ} \mathrm{C}$ and $\mathrm{pH} 3.0$ at $85^{\circ} \mathrm{C}$ by adding $\mathrm{Ca}(\mathrm{OH})_{2}(3.4 \mathrm{~g} / l)$ as previously reported ${ }^{62-0)}$.

Operation and conditions for ultrafiltration

The apparatus used for ultrafiltration was a UHP-76 (Toyo Kagaku Sangyo Co., Ltd.), which was a batch-type filtration unit equipped with a stirrer. Three membranes of two types were used in this study : XM-50 and XM-100 (Amicon Co., Ltd.), and A-50 T (Bioengineering Co., Ltd.). These membranes had nominal molecular weight exclusion limits of 50000 , 100000 , and 50000 , and the flow times of water for the initial $10 \mathrm{ml}$ were $2.0,4.0$, and 8.0 sec, respectjvely. The $\mathrm{XM}$ and $\mathrm{A}-50 \mathrm{~T}$ membranes are reportedly made of an acrylic vinyl co-polymer and collulose acetate, respectively. The juice applied $(400 \mathrm{ml})$ was ultrafiltered until a permeation volume of $370 \mathrm{ml}$ was reached $\left(700 \mathrm{rpm}, 4.0 \mathrm{~kg} / \mathrm{cm}^{2}\right.$, and 67 and $55^{\circ} \mathrm{C}$ ). As the maximum ternperature for A$50 \mathrm{~T}$ membrane was $55^{\circ} \mathrm{C}$, ultrafiltration was performed at $55^{\circ} \mathrm{C}$ when the mernbrane was ured.

\section{Sucrose measurements}

The Brix (Bx) degree of the permeated juice was measured with a refractometer and a spindle without clarification. The sucrose content was also measured with a saccharimeter after clarification with dry basic lead acetate for raw and limed juice.

\section{Results}

The flux rate is shown in Fig. 1 as a function of the permeate volume of the raw juice for the $X M-50, X M-100$ and $A-50 T$ membranes. The flux rate through the all of mernbranes used remained at a value of 0.09 $0.100 \mathrm{ml} \cdot \mathrm{cm}^{-2} \cdot \mathrm{min}^{-1}$ until a volume of $250 \mathrm{ml}$ was reached, but it then decreased gradually. A decreasing flux rate may be due to the deposit of some colloids such as proteins and polysaccharides on the membrane surface ${ }^{\text {"8) }}$.

The qualities of the permeates are summarized in Table 1. The permeates thus obtained were of $17-20^{\circ} \mathrm{Bx}$ and $87-90 \%$ purity. Sucrose rejection was high, 5-9\%, with the $A-50 \mathrm{~T}$ membrane, while XM-50 and XM-100 membrenes showed low velues, 2-3\%. This may be due to the adsorption of proteins and polyseccharides as mentioned ahove, and these results agree with the flux data shown in Fig. 1.

Effect of degree of liming on flux through the XM-50, XM-100 and A-50 T membrane is shown in Fig. 2. Liming was performed at 10 and $85^{\circ} \mathrm{C}$ and flux was calculated on basis of the first $50 \mathrm{ml}$ of permeate. The largest flux of permeate was obtained at $\mathrm{pH} 8.1$ and $\mathrm{pH} 7.0$ when liming was performed at 10 and $85^{\circ} \mathrm{C}$, respectively. This result agreed with that

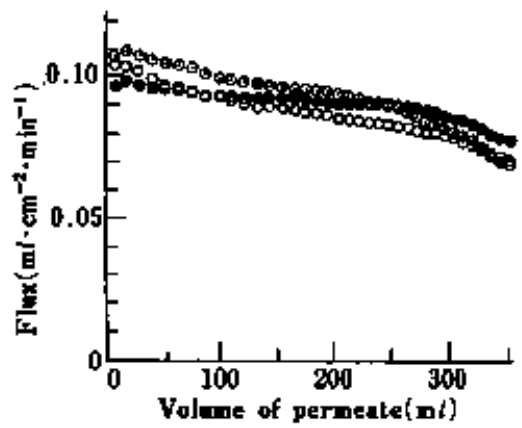

Fig. 1 Permeation flux of raw juice as a function of permeation volume al 67 and $55^{\circ} \mathrm{C}$

The membranes used were XM-50, XM-100 and $\mathrm{A}-50 \mathrm{~T}$ membranes. Ultrafiltration was performed under the following conditions: Pressure, $4.0 \mathrm{~kg} / \mathrm{cm}^{2}$; stirring speed, $700 \mathrm{rpm} ;$ temperature, $67^{\circ} \mathrm{C}$ for $\mathrm{XM}-50$ and $\mathrm{XM}-100$ membrene and $55^{\circ} \mathrm{C}$ for $\mathrm{A}-50 \mathrm{~T}$ membrane.

$$
0, \mathrm{XM}-50 ; \odot, \mathrm{XM}-100 ; \circ, \mathrm{A}-50 \mathrm{~T} \text {. }
$$


obtained from PM and YM membranes as reported previously ${ }^{87)}$. Furthermore, fux rate of juice limed at $85^{\circ} \mathrm{C}$, showed very large values, about twice as large as those of juice limed at $10^{\circ} \mathrm{C}$. This indicates that hot liming, at $85^{\circ} \mathrm{C}$, is more efficient for inereasing the flux than cold liming, and these resultis agree with the results obtained from PM-10, YM-5 and YM-2 membranes as reported previously"n,

The limed juice adjusted to pH 8.1 at $10^{\circ} \mathrm{C}$

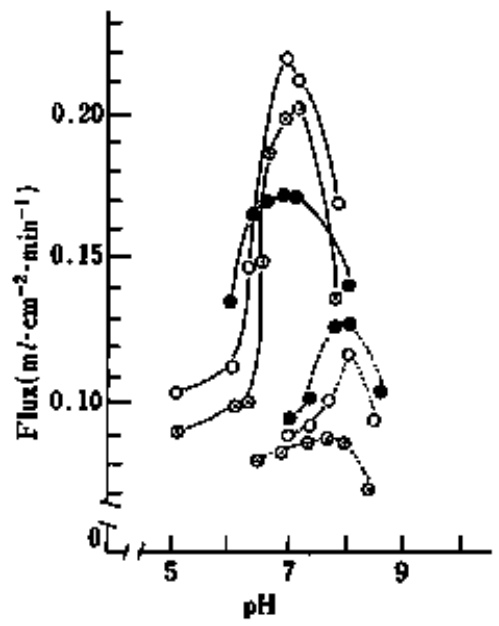

Fig. 2 Effect of degroe of liming on flux at 67 and $55^{\circ} \mathrm{C}$

Juice was limed at $10(----)$ and 85 (-) C. Flux was calculatad on basis of the $50 \mathrm{~m} l$ of permeate.

$0, \mathrm{XM}-50 ; \odot, \mathrm{XM}-100 ; \odot, \mathrm{A}-50 \mathrm{~T}$. was ultrafiltered through the XM-50, XM-100 and A-50 T membranes, and the flux obtained are shown in Fig. 3. The A-50T membrane gave the greatest value of $0.14 \mathrm{ml} \cdot \mathrm{cm}^{-2}$. $\mathrm{min}^{-1}$ at the initial stage, however the value decreased gradually with increasing permeate volume. The flpx with the XM-100 membrane was lower than that for non-treated juice as shwon in Fig. 1. This may be dae to the occurence of considerable colloidals adsorption on the membrane materials.

Figure 4 shows the flux-permeate relationship of juice limed to $\mathrm{pH} 7.0$ at $85^{\circ} \mathrm{C}$. The flux through the XM-50 and XM-100 membranes

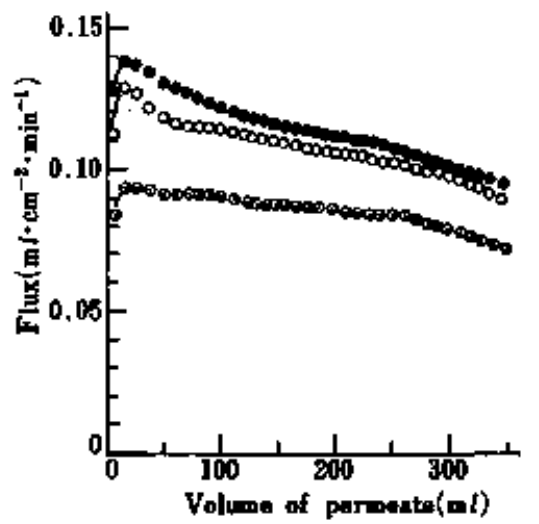

Fig. 8 Permeation fux of juice limed to $\mathrm{pH} 8.1$ at $10^{\circ} \mathrm{C}$ as a function of permeation volume at 67 and $55^{*} \mathrm{C}$ $\mathrm{O}, \mathrm{XM}-50 ; 0, \mathrm{XM}_{\mathrm{M}}-100 ; \bullet, \mathrm{A}-50 \mathrm{~T}$.

Table 1 Sucrose contents of raw juice permeated with XM-50, XM-100 and $\mathrm{A}-50 \mathrm{~T}$ membranes at 67 and $55^{\circ} \mathrm{C}$

\begin{tabular}{|c|c|c|c|}
\hline & Sucrose $(\%, w / v) *$ & Bx (Spindle) & $\mathrm{Bx}$ (Ref) \\
\hline \multicolumn{4}{|l|}{$\mathrm{XM}-50$} \\
\hline Sucrose & 18.2 & 18.0 & 18.8 \\
\hline Sucrose rejection (G)" & 3.1 & 5.0 & 3.1 \\
\hline \multicolumn{4}{|l|}{$x M-100$} \\
\hline Sucrose & 18.2 & 20.5 & 18.6 \\
\hline Sucrose rejection (\&)" & 3.7 & 2.4 & 3.2 \\
\hline \multicolumn{4}{|l|}{$A-50 T^{b}$} \\
\hline Sucrose & 17.8 & 18.5 & 17.6 \\
\hline Sucrose rejection (\%) & 9.4 & 7.5 & 5.1 \\
\hline
\end{tabular}

"Measurement was performed after clarifacation with dry basic lead acetete.

- Sucrose rejection $=(1-$ permeated juice/feed juice $) \times 100$

bitrafiltration was performed at $55^{\circ} \mathrm{C}$. 
showed remarkably large values at initial stage. However, it decreased rapidly until a volume of $100 \mathrm{ml}$ was permeated and remained constant at $0.100 \mathrm{ml} \cdot \mathrm{cm}^{-2} \cdot \mathrm{min}^{-1}$. On the contrary, the A-50 T membrane gave comparatively lower values than XM-50 and XM- 100 membrane at the initial period, the greatest value among the three membranes being given

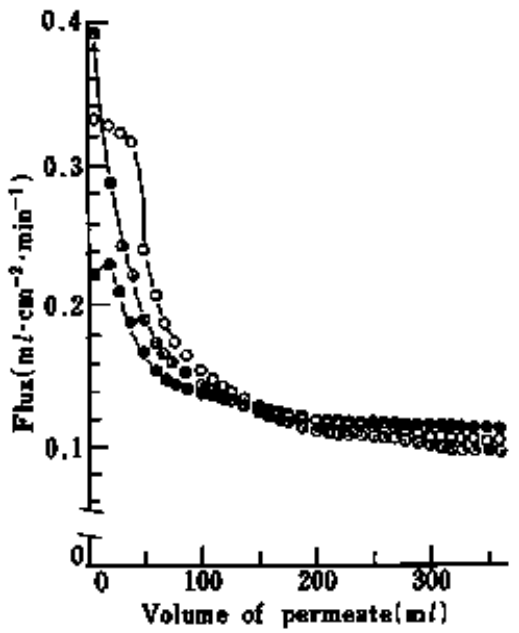

Fig. 4 Permeation flux of juice limed to pH 7.0 at $85^{\circ} \mathrm{C}$ as a function of permeation volume at 67 and $55^{\circ} \mathrm{C}$

$0, \mathrm{XM}-50 ; 0, \mathrm{XM}-100 ; 0, \mathrm{~A}-50 \mathrm{~T}$. after a permeation volume of $200 \mathrm{ml}$ had been reached.

The quality of juice limed to $\mathrm{pH} 8.1$ (7.0) at $10(85)^{\circ} \mathrm{C}$ and ultraflitered through the various membranes is summarized in Table 2. The aucrose rejection with XM membranes was higher than that with A-50 T membrane in cald liming $\left(10^{\circ} \mathrm{C}\right)$ test. However, in hot liming $\left(85^{\circ} \mathrm{C}\right)$, the reverse correlation was obaerved; nemely, the $\mathrm{A}-50 \mathrm{~T}$ membrane which had a molecular weight cut-off level of 50000 showed the highest sucrose rejection of $5.2 \sim 7.0 \%$. Whereas the sucrose rejection was $2.5 \sim 3.5 \%$ with the XM-100 membrane, which had a molecular weight cut-off level of 100000 , it was the lowest, $2.1 \sim 2.49 \%$, with the $\mathrm{XM}-50$ membrane, which had a molecular weight cutoff level of 50000 .

Experimental results were also obtained for a pure sucrose solution $(17.5 \%, w / v)$, as shown in Fig. 5. In both experiments with $\mathrm{XM}-50$ and $\mathrm{XM}-100$ membranes, the flux was observed to be remarkably high during the initial period, and then it decreased with increasing permeate volume. As for the $\mathrm{A}^{-}$ $50 \mathrm{~T}$ membrane, a comparatively large increase in the flux was observed as compared to that of the cane juice limed to $\mathrm{pH} 7.0$ at $85^{\circ} \mathrm{C}$ (Fig. 4), The sucrose rejection for pure sucrose

Table 2 Suerase contents of limed juice permeated with XM-50, XM-100 and A-50T membranes at 67 and $55^{\circ} \mathrm{C}$

\begin{tabular}{|c|c|c|c|c|}
\hline & & Sucrose $(\%, w / v)$ & Bx (Spindle) & $B x(R \in f)$ \\
\hline \multirow[t]{4}{*}{$X M-50$} & Limed to $\mathrm{pH} 7.0$ at $95^{\circ} \mathrm{C}$ & 18.2 & 20.5 & 18.6 \\
\hline & Sucrose rejection $(\mathscr{C})^{4}$ & 2.1 & 2.4 & 2.1 \\
\hline & Limed to $\mathrm{pH} 8.1$ at $10^{\circ} \mathrm{C}$ & 17.2 & 17.0 & 16.6 \\
\hline & Sucrose rejection $(\mathscr{C})$ " & 14,9 & 10.0 & 4.1 \\
\hline \multirow[t]{4}{*}{$\mathrm{X} M-100$} & Limed to $\mathrm{pH} 7.0$ at $85^{\circ} \mathrm{C}$ & 18.1 & 20.0 & 18.0 \\
\hline & Sucrose rejaction $(\mathscr{C})$ ' & 3.5 & 2.5 & 3.1 \\
\hline & Limed to $\mathrm{pH} 8.1$ at $10^{\circ} \mathrm{C}$ & 18.4 & 17.5 & 16.8 \\
\hline & Sucrose rejection $(\mathscr{C})^{\prime}$ & 12.1 & 11.0 & 11.8 \\
\hline \multirow[t]{4}{*}{$\mathrm{A}-50 \mathrm{~T}^{\prime}$} & Limed to $\mathrm{pH} 7.0$ at $86^{\circ} \mathrm{C}$ & 16,3 & 18.0 & 16.6 \\
\hline & Sucrose rejection $(\omega) \cdot$ & 7.0 & 5.2 & 5.6 \\
\hline & Limed to $\mathrm{pH} \mathrm{B.1}$ at $10^{\circ} \mathrm{C}$ & 16.3 & $17 . .5$ & 16.6 \\
\hline & Sucrose rejection $(\mathscr{6})^{*}$ & 12.2 & 7.9 & 6.7 \\
\hline
\end{tabular}

- Sucrase rejection = (1-permeated juice/feed juica $) \times 100$

'Ultrafiltration was performed at $55^{\circ} \mathrm{C}$. 


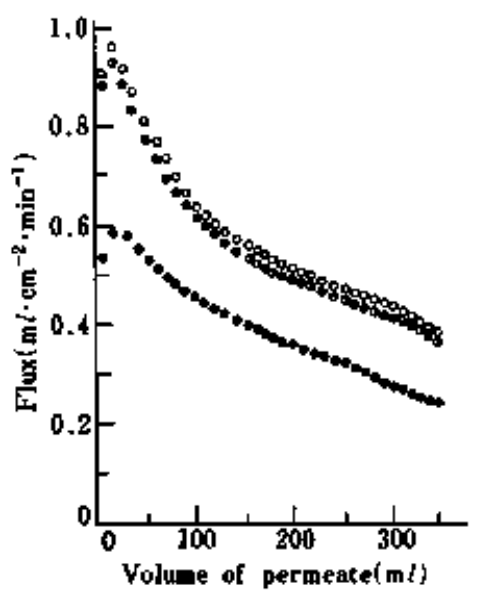

Fig. 5 Permeation flux of a sucrose solution as a function of permeation volume at 67 and $55^{\circ} \mathrm{C}$

The sucrose solution used was 17.5 $\%, w / v$.

$0, \mathrm{XM}-50 ; 0, \mathrm{XM}-100 ; 0, \mathrm{~A}-50 \mathrm{~T}$.

solutions was very low, $0 \sim 2.0 \%$, with both $\mathrm{XM}$ and A-50 T membranes (not shown in the Table).

\section{Discussion}

In order to compare the flux and quality of cane juice permeated with XM-50, XM-100 and A-50 T membranes with those with YM membranes, experiments were performed under the same conditions as in the previous study ${ }^{8)}$. In spite of the greater flux through the YM-30 membranes), which had nominal molecular weight exclusion limit of 30000 , and was reportedly made of a cellulose derivative, the A-50 T membrane, which had nominal molecular weight exclusion limit of 50000 , and was made of cellulose acetate, showed lower values for raw juice. The result obtained was contrary to our expectation. This suggests that the cellulose acetate membrane (A-50 T) became more liable to adaorb some colloids such as proteins and polysaccharides aven of being formerly globular in shape, when its molecular weight exclusion limit of 50000 was used. However, for juice limed to $\mathrm{pH} 8.1$ at $10^{\circ} \mathrm{C}$, the $\mathrm{A}-50 \mathrm{~T}$ membrane gave the greatest flux during ultrafiltration, and furthermore it showed larger values than those with YM-5 membrane ${ }^{8 /}$ for juice limed to $\mathrm{pH} 7.0$ at $85^{\circ} \mathrm{C}$.

Although, XM-membranes $\mathrm{XM}-50$ and $\mathrm{XM}-1 \mathrm{O}$ ) showed low flux for the raw juice and the juice limed to $\mathrm{pH} 8.1$ at $10^{\circ} \mathrm{C}$, for the juice limed to $\mathrm{pH} 7.0$ at $85^{\circ} \mathrm{C}$, it gave very large flux, showing 0.390 and $0.330 \mathrm{ml} \cdot \mathrm{cm}^{-2} \cdot \mathrm{min}^{-1}$ at the initial stage. The values ware twice as large as $P M-30, P M-10, Y M-5^{8)}$ and $A-50 T$ membranes at the period, while it then docreased rapidly with increasing permeate volume, the value being 0.120 and $0.110 \mathrm{ml}$ * $\mathrm{cm}^{-2} \cdot \min ^{-1}$ at the permeation volume of $200 \mathrm{~m} l$. After that, it remained constant until the volume of $370 \mathrm{ml}$, at which, however, the flux was larger than with YM-5 membrane as reported previously ${ }^{8}$.

In spite of showing larger flux with A-50 T membrane than with YM-5 membrane ${ }^{83}$, the sucrose rejection for the former mernbrane was greater then that for the latter one for juice limed to $\mathrm{pH} 7.0$ at $85^{\circ} \mathrm{C}$. This indicates that there is a remarkable difference in sucrose concentration between the residual and permo ated juice when ultrafiltration is performed with A-50 T membrane. This may be due to the remarkable adsorption of proteins and polysaccharides that takes place on the membrane surface. It cannot be concluded whether the result depends on the quality of the membrane material (cellulose acatate) or on the operation temperature $\left(55^{\circ} \mathrm{C}\right)$. Thus, $\mathrm{A}-50 \mathrm{~T}$ membrane is difficult to use in the sugar industry. The lowest sucrose rejection was obtained with the XM-50 membrane, the value being $2.1 \%$ for the juice limed to $\mathrm{pH} 7.0$ at $85^{\circ} \mathrm{C}$, while it remained at $2.5 \sim 3.5 \%$ with the $\mathrm{XM}-100$ membrane.

On ultrafiltration of limed juice with all of membrane uaed, some dark brown deposit was formed on the membrane surface. The deposit on the XM-50, XM-100 and $\mathrm{A}-50 \mathrm{~T}$ membranes was removed by washing with 0.05 $\mathrm{N} \mathrm{NaOH}$ at $50^{\circ} \mathrm{C}$ for 20 min, and the membrane capacity was restored. A big problem in ultrafiltration is the fouling of membrane". This could cause serious disruption of sugar production and limit the economic viability of 
the procrss.

Thus, on the basis of Results and Discussion, wo conclude that the XM-50 membrane which is reportedly made of an acrylic vinyl co-polymer is suitable for juice limed to $\mathrm{pH} 7.0$ at $85^{\circ} \mathrm{C}$ (hot liming). The next stage in this study is large scale operation with an XM membrane, using a batch-type filtration apparatus and other systems such as tubular, spiral wound and hollow-fibre ones.

\section{References}

1) KishiHara, S., Fumi, S. and Komoro, M. ; Membrane, 5, 86 (1980).

2) MaDsen, R.F.: Int. Sugar J, 75, 183 (1973).

3) VANB, G.W.: Sucr, Belge, \$6, 277 (1977).

4) Hanssens,T.R., Van NISEEN, J.G.M., Korrts, K. and de NIB, L.H. : Int. Sugar J., 86, 227 (1984).

5) Hanssens, T.R., Van Nisp3n, J.G.M., Korrts, K. and de Nis, L.H. : Int. Sugar $J ., 86,240$ (1984).

6) Tako, M., Nakayama, Y., NaknuURa, S., KISHTHARA, S. and Komoto, M.: Nippon Nögeikagaku Kaishi, 58, 685 (1984).

7) Tako, M., Takara, M. and Nakamura, S.: Nippon Nogeikagaku Kaishi, 58,779 (1\%5).

B) Tako, M. and Naknutura, S. : Agric. Biol. Chem., 50, 833 (1986).

9) OrYA, H. : Maku Riyou Gijutsu Handbook
II (Saimai Shobou), p. 959 (1983).

(Receifed Dec. 20, 1986)

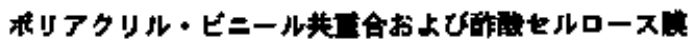

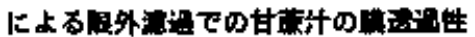

田幸正邦* - 仲本邦也* - 仲村实久* *

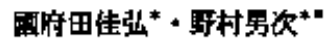

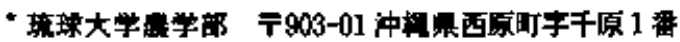

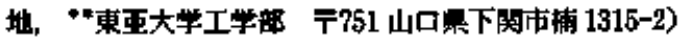

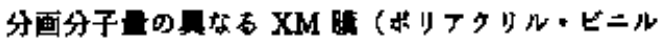

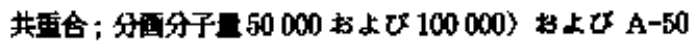

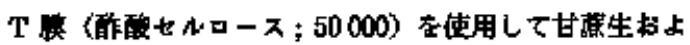

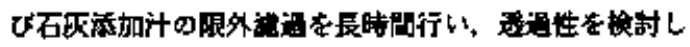

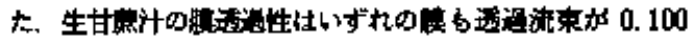

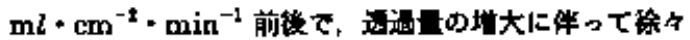
に沟少した. $10^{\circ} \mathrm{C}$ で pH8.1に水化カルシウムだ

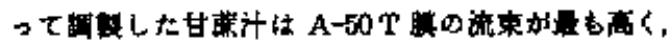

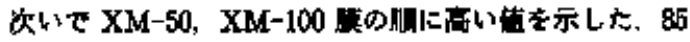

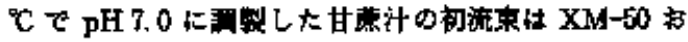

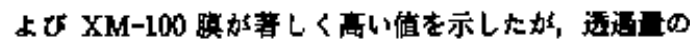

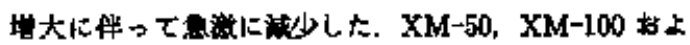

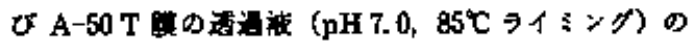

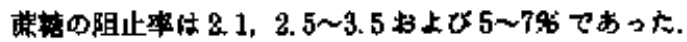

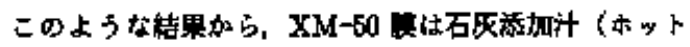

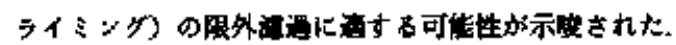

